\title{
Strategic Issues Affecting Training and Development in Tanzania's Public Sector: Evidence from Selected Local Government Authorities
}

\author{
Venance Shillingi Salum \\ Lecturer, Mzumbe University, Tanzania \\ School of Public Administration and Management \\ Stella Malangalila Kinemo \\ Senior Lecturer (PhD), Mzumbe University, Tanzania \\ School of Public Administration and Management \\ Moses Daniel Kwayu \\ Assistant lecturer, Mzumbe University, Tanzania \\ School of Public Administration and Management \\ Zuena Kilugwe Khamis \\ Lecturer, Mzumbe University, Tanzania \\ School of Public Administration and Management
}

Received: July 4, 2018 Accepted: Sep 1, 2018 Online published: Sep 12, 2018

doi:10.5296/jpag.v8i3.13638 URL: https://doi.org/10.5296/jpag.v8i3.13638

\begin{abstract}
This paper examined strategic issues affecting training and development in Tanzania's public sector with evidence from selected local government authorities. The specific objectives were to examine whether organisation resources, modern technology, organisation structure, and organisation culture affects training and development in organisations. Tools for data collection were questionnaires, interviews and documentary review, which were used to
\end{abstract}


collect data Dodoma and Chamwino local authorities, then data were analyzed using SPSS version 20 and excel spreadsheet. The findings revealed individually and collectively independent variables (organisation resources, modern technology, organization structure and organisation culture) affects training and development, where coefficient of determination $\left(R^{2}=0.762\right)$ implied $76.2 \%$ of the variations in training and development was influenced by organisation resources, modern technology, organisation structure and organisation culture in two local authorities. This means that other factors not studied in this research contributes about $23.8 \%$ only, with higher influence being from organisation resource at $\beta=0.448$; modern technology with $\beta=0.253$; organisation structure with $\beta=0.200$; and organisation culture with $\beta=0.124$ respectively. Therefore, management in local authorities should consider these strategic issues for effective execution of training and development of employees towards improving council's service delivery.

Keywords: training, financial resources, modern technology, organisation structure, organization culture, public sector

\section{Introduction}

The constant change availed by environmental factors and globalization in the 21 st century has pushed organisations in both public and private sector to render a new sense of urgency to businesses in the organization strategy to ensure survival and prosperity of their organizations (Pearce \& Robinson, 2009). Human resource being source of competitive advantage in today's firms, and hence training and development fuels competency and capabilities to an organization in order to boost competitiveness. Also, employees in an organization have to be trained to ensure improved skills to cope with changes in business environment (Wheelen \& Hunger, 2000). Well-trained workforce and educated employees in a firm is considered to be essential value-addition to the maintenance of an organizations competitive advantage in a global economy (Armstrong, 2006). Most organizations in developed countries are obligated to continuous developing and training their human resource. Employees training should be on-going process but not one-time affair at the time of their recruitment. Due to globe change of business environment, whenever a new technology or production process is introduced, managers and workers are re-trained to enable them to master it (Noe, 2008).

In addition, the primarily focus of training according to Noe (2008) is on imparting organizational employees with required knowledge and skills needed to perform their current jobs effectively while development focuses on building knowledge and skills of organization employees to be prepared for new challenges and responsibilities in future (Lado \& Wilson, 2004). Employees are valuable assets in any organisation weather in public, private or third sector, organization should increase development of human resources to widen and enhance employees' skills those enable them to make better use of their knowledge, skills, attitudes (Armstrong, 2006). Further, training and development of employees is affected by various factors including development of new products, training budget, employee performance, relevance of the programmes, technology but also the prevailing labour requirements and legislation (Lado \& Wilson, 2004).

Moreover, like organizations in developed countries, firms in developing countries needs 
training and development which is essential for upholding human resource potential within organization and not to be considered as an ad-hoc operational issue that increases costs but as part and parcel of core strategy of an organization that increases competitiveness (Lado \& Wilson, 2004). It aims at achieving measurable goals articulated in terms of improved performance or expected changes at organisational, departmental, or at individual level (Ngirwa, 2009). This should help in attaining each training program in relation to its planned objectives by reflecting assessment of training needs within three levels of organisation, which include organizational, job level and individual level (Noe, 2008). Indicators such as number of accidents, mistakes, production records, operations expansions, new technology, promotions, labour turnover, and transfers should inform the need for training and development in an organisation (Ngirwa, 2009). Therefore, the main study purpose aimed at establishing strategic issues affecting Training and development in Tanzania's public sector; where study was guided by four research hypotheses: organisation resources, modern technology, organization structure, and organisation culture positively effects training and development in Tanzania's local government.

\section{Literature Review}

\subsection{Training and Development}

Training and development is deliberately used to bridge performance gap between existing and anticipated future performance in the organization (Barrington \& Stimpson, 2002). It falls under human resource development function (Guest, 1987). This function identifies training and development needs, methods selected, suitability of programmes, implementation plans and finally outcome results are evaluated (McCourt \& Eldridge, 2003). Training policies are necessary to ensure evaluation of employee performance that ensures appropriate training and development to be conducted (Guest, 1987). Moreover, performance appraisal reports help organization to identify development needs. Though, employees when involved in the assessment helps in indicating areas compelling intervention on issues raised during appraisal process of employee's performance and career development.

\subsection{Training in Local Government}

Decentralization by Devolution (D by D) was introduced in Tanzania to empower the Local Government Authorities to improve service delivery. Local Government Reform Programme (LGRP) has been done in two phases since 2000. Apart from introducing LGRP challenges in local government still remain including capacity development training for local government staff. In 2009/2010 the Prime Minister's Office - Regional Administration and Local Government (PMO-RALG) developed Training Strategy for Local Government Authorities with a purpose of improving training. The purpose of the strategy was to ensure effective training for the staff of Local Government Authorities. According to the Training Strategy (2010) the policy goals are to ensure a well organized, coordinated system of training and development of staff in the public sector and to provide guidance for the efficient, effective training of human resources and their subsequent utilization. Basing on the Training Strategy (2010) the first objectives of the strategy is to provide clear guidance, standards and priorities for the efficient and effective training and development of 
human resources and their subsequent utilization in the LGAs, with a view to enhance job performance of their personnel and service delivery. The second objective is to ensure that staff training is an integral part of efforts for career advancement and orderly succession in the LGAs and that all staff will have equitable opportunities to access necessary training to ensure desired levels of job performance. The third objective is to create a more effective, stream-lined institutional arrangement for training service provision, including clear division of roles for stakeholders. Lastly to establish an appropriate mechanism for quality assurance of training. Apart from formulating the training strategy local authorities are still facing challenges in training and developing staff.

\subsection{Theories Underlying This Study}

This study was guided by two theories namely; human capital and resource-based theory in order to study strategic issues affecting training and development in Tanzania's public sector with evidence from selected local government authorities.

\subsubsection{Resource Based Theory}

According to Russo and Fouts (2007) organisation resources are classified into tangible, intangible and human; where in respect to tangible resources, these include raw materials, tools, facilities, financial reserves, plant, and equipment, where intangible resources encompass goodwill, reputations, and technology. Also, human resources comprise of expertise of employees, skills, competences, abilities, culture, loyalty and their commitment to the organization.. The theory therefore, underscores the firm's resources as the basic factors for firm performance and sustainable competitive advantage through accelerating competency development that are exclusive to the organisation and shared relationships which are rooted in an organization's culture and history, and create tacit knowledge to the organization (Lado \& Wilson, 2004). Its application is that, resources and capabilities of the firm play a vital role to acquire competitive advantage within a particular industry.

\subsubsection{Human Capital Theory}

According to Gordon (2002) human capital theory entails not only the years of schooling, but also investments such as training, school quality, attitude towards work, and the like. Labor economics describe human capital as a set of features or abilities that increase employee's productivity. It is an asset that produces benefits and income for long-term period is termed as capital. Moreover, training and education are valued resources for firms and investing in them rises incomes, skills, and knowledge (Harrison, 2000)). Therefore, human capital theory through investing in training and development, the firm expects future benefits that increases employee productivity, job satisfaction and motivation of employees.

\subsection{Strategic Issues Affecting Training and Development}

This section provides literature on strategic issues affecting training and development in Tanzania's public sector. Strategic issues discussed include organisation resources, modern technology, organisation structure and organisation culture. 


\subsubsection{Organizational Resources}

Okioga (2012) argue that firm resources include trained employees, capital, and networks in the form of strategic alliances, funds, techniques, processes, and human. Firm resources help to develop strong capability which in return creates a competitive edge which is difficult to be replicated by other competitors within any given sector of economy. Also, Abok (2013) concur that, material wealth, knowledge resources, and organization ability are very vital for successful execution of strategies. Strategies at business level are determined by the efficiency management of resource, allowing the firm to compete successfully in a very competitive environment (Jarzabkowski \& Balogun, 2009). Further, efficient utilization of resources boosts capacity for desired strategic competitiveness. So, poor management of resources leads to frequent failures in implementation of strategies in private, public or voluntary sector (Okioga, 2012). Moreover, for successful execution of firm objectives, there is need for trained managers who organize, coordinate and manage sustainable use of firms' valuable resources. Therefore, resources adequacy such as human and financial play a big role in supporting and encouraging employees training and development.

\subsubsection{Modern Technology}

According to Torrington and Chapman (2008) information age has swept the entire world where globalization and fast technological development have caused continuous shift of skills, knowledge and abilities of employees to discharge their day to day activities. This situation has triggered the necessity for training and development to cope with this demand availed by external environment in respect to technological changes as well as globalization (Huang, 2001). Therefore, organisations have given training and development good attention in recent years in order to match with rapid technological changes that compromise unskilled works steering jobs and demanding knowledge which can cope with new technology.

\subsubsection{Organizational Structure}

According to Noe (2008) for successful training and development, a firm need an organizational structure which is flexible to support and enable job designs and redesigns to accelerate on-job training and provide reflection time as well as lesson sharing after training. Meanwhile, inflexible structure of the firm hinders training initiatives and acts as an impeding factor (Ngirwa, 2009). Moreover, organisation structure may define or influence training and development. For instance, innovative and flexible structure will desire training to cope with changes. Therefore, structure of the firm determines the presence and role of the employees' functions which are directly linked with organisation strategies.

\subsubsection{Organization Culture}

Organisation culture entails internal integration that determines togetherness, communication on daily basis, collective identity, behaviour which is acceptable, and allocation of powers in the structures of organization (Hill \& Jones, 2013). This will help in external adoption when dealing with external stakeholders while implementing training and development in organisation. Chen (2007) argued that, organisational environment will mostly affect how culture relates to training and development. This can lead to an externally focused or 
"mission" culture which emphasizes on adaptability, or on the other hand, an internally focused culture such as a bureaucratic culture or "clan-based" type of culture. Corporate culture, then, refers to leadership styles of managers, including how they make decisions, the way time is spent, the focus on attention, relations with employees, and how the day to day activities of the organisation are managed. Also, Awino (2007) argues that organisation culture demands togetherness and collective identity to determine acceptable or unacceptable behaviours, power allocations and day to day communications within the firm. Moreover, according to Hill and Jones (2013), as a strength, culture can facilitate decision making, communication and control, can also build commitment and cooperation; whereas as a weakness, culture may deter the smooth implementation of strategy by generating resistance to change from employees. This study therefore assessed the important question of how culture influences training and development in Tanzania's public sector.

\subsection{Conceptual Framework}

Conceptual framework is a model hypothesizing independent and dependent variables and their relationship in a given study. It makes a logical sense of the relationship among different variables identified as significant to the problem under study (Sekaran \& Bougie, 2009). This model helps to suggest, hypothesize and test certain relationship in order to improve our understanding of the situation which is complex or dynamic.

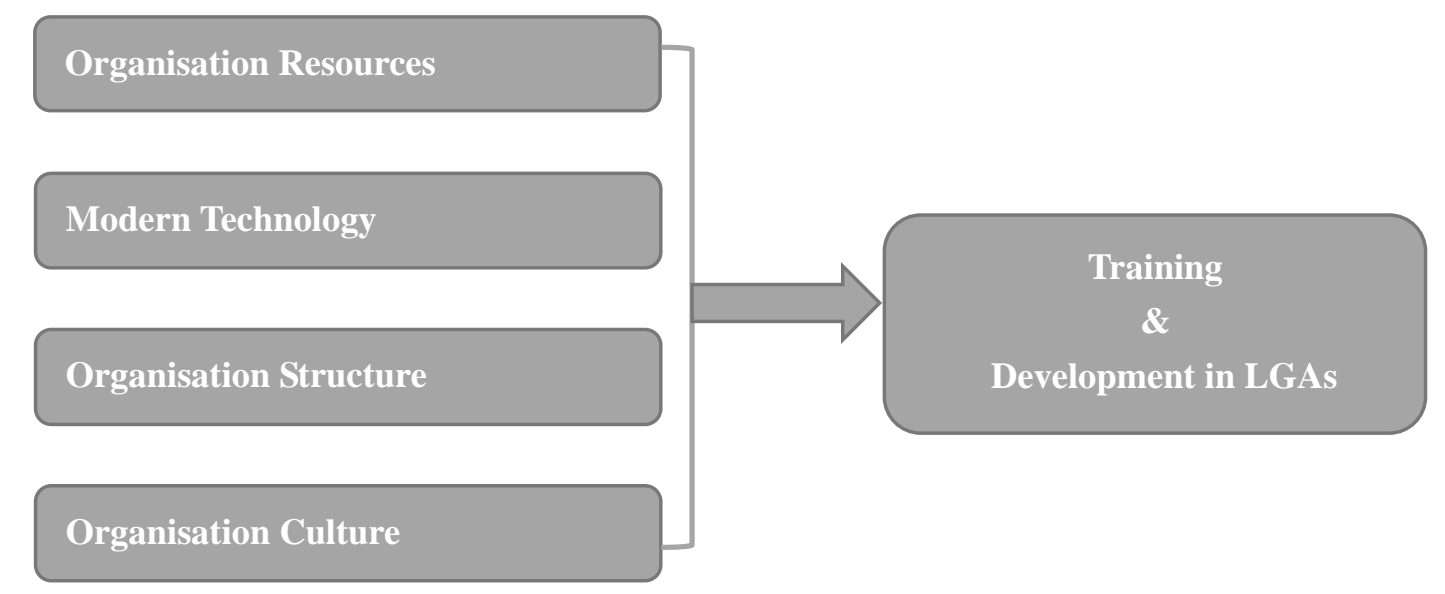

Figure 2.1. Conceptual Framework

In respect to figure 2.1 in this study, it is under assumption that training and development in an organization is affected by different strategic issues, among others, this study considered organisation resources, modern technology, organisation structure and organisation culture in Tanzania's public sector; and examined their relationship with training and development. The availability of financial resources in the organization influences the possibility of staff being trained. Training presents opportunity to staff to gain knowledge and skills at work place. Change of technology can force an organization to train staff so that they can cope with new ways of working. Moreover the culture of the Organization on training of staff can influence implementation of training activities at work place. An organization with a training and development culture will always support continuous training of staff. Organization 
structure may influence implementation of training and development to staff. An organization which is flexible can support training to staff whenever need arises compared to an organization which has inflexible structure. New technology influences training and development of staff due to new skills and knowledge which are being introduced now and then.

\section{Methodology}

The study employed a case study design to investigate whether organisation resources, modern technology, organization structure, and organization culture influence training and development in local authorities in Tanzania. Studies were carried out in Chamwino District Council and Dodoma Municipal Council in Dodoma region. Target population was 224 employees in two local government authorities. The descriptive research design was used to investigate variables in this study where some particular contemporary phenomena within their natural context or setting were studied using multiple sources of evidence (Robson, 2002). This allowed use of mixed techniques such as qualitative and quantitative as well as a combination of data collection tools such as interview, questionnaire and documentary review which facilitated collection of data. Interview was conducted to 20 key informants. These include three officials from Prime Minister's Office- Regional Administration and Local Government (PMO-RALG), two directors of the local authorities, five Human Resource Officers, six heads of departments and four councilors. One set of a structured questionnaire was prepared and pretested before being used as the main data collection instrument. The structured questionnaires were administered to 47 staff of the two local authorities. The study used stratified random sampling and purposive sampling to choose the sample size and respondents of this study. The sample size of 67 which was $30 \%$ of the target population from two local authorities was drawn using stratified random sampling. Also, purposive sampling was used to obtain key informants for follow-up interviews in order to supplement information obtained from questionnaires. As indicated by Kothari (2008) that, any large sample to be at least $10 \%$ of the target population. Table 3.1 represents sample composition of this study. Qualitative data obtained were analysed through content analysis. The data were analyzed qualitatively and quantitatively where qualitative data was analyzed through content analysis while quantitative data were analyzed using descriptive and inferential analysis. Tables, figures, p-value, t-test, F-test, $\mathrm{R}$ and $\mathrm{R}$ Square were used to interpret the findings analyzed using SPSS version 20.

Table 3.1. Study Sample Size Composition

\begin{tabular}{lll}
\hline Local Authority & Target Population & Sample Size (30\%) \\
\hline Dodoma Municipal Council & 104 & 31.2 \\
Chamwino District Council & 120 & 36 \\
Total & $\mathbf{2 2 4}$ & $\mathbf{6 7}$ \\
\hline
\end{tabular}

Source: Field data, 2017

\section{Findings and Discussion}

Training and development is a key for skills, knowledge and abilities improvement in any 
organisation directed towards job related tasks. This study investigated strategic issues affecting training and development in Tanzania's public sector, with evidence from selected local authorities. The presentation is categorized into descriptive and inferential analysis.

\subsection{Descriptive Analysis}

This section presents descriptive analysis in relation to variables influencing training and development in Tanzania's public sector. The independent variables included: organisation resources, modern technology, organisation structure and organisation culture while the dependent variable was training and development. The descriptive analysis described each specific objective separately.

\subsubsection{Organisation Resources}

The study investigated if there are specific organisation resources which affect training and development in Tanzania's public sector. The results in table 4.1 indicates out of 67 respondents, majority about $68.5 \%$ pointed out availability of resources which act as obstacles towards training and development while $31.5 \%$ did not see any obstruction as far as training and development is concerned. The most mentioned resources by employees in two local authorities which hinder training and development include:

"Financial resources, shortage of skilled and semi-skilled personnel, lack of internal trainers, lack of modern training facilities, lack of training programs" (Interviews, namewithheld, Dodoma \& Chamwino, $20^{\text {th }}$ June to $18^{\text {th }}$ July 2017).

Table 4.1. Specific Resources that Hinder Training and Development

\begin{tabular}{|c|c|c|c|c|}
\hline \multicolumn{5}{|c|}{ Frequency Percent Valid Percent Cumulative Percent } \\
\hline Yes & 46 & 68.6 & 68.6 & 68.6 \\
\hline No & 21 & 31.3 & 31.3 & 100.0 \\
\hline Total & 67 & 100.0 & 100.0 & \\
\hline
\end{tabular}

Source: Field data, 2017

The findings agree with other scholars such as Wheelen and Hunger (2000) who argued that firm resources are the basis for power over other organisations. Also, Okioga (2012) argues that a firm's resources must reduce threats and should have ability to exploit opportunities in the environment. Thus, it is clear that organisations with rare, valuable, non-substitutable and inimitable resources can easily execute their training and development programmes towards achieving organisation objectives. Moreover, on the issue whether organisation resources such as financial, material and information resources affect training and development in Tanzania's public sector. The results on figure 4.1 revealed out of 67 respondents, majority about $61.0 \%$ agreed and $21.0 \%$ strongly agreed while $5.0 \%$ were neutral. The rest few about $9.0 \%$ and $4.0 \%$ of respondents disagreed and strongly disagreed respectively. However, some challenges which were pointed out by respondents in relation to organisation resources include:

"Insufficient budget to fund training, lack of clear training programme, individual 
long-term trainings are not full supported" (Interviews, Namewithheld, Dodoma Municipal Council headquarter, $18^{\text {th }}$ June to $19^{\text {th }}$ July 2017).

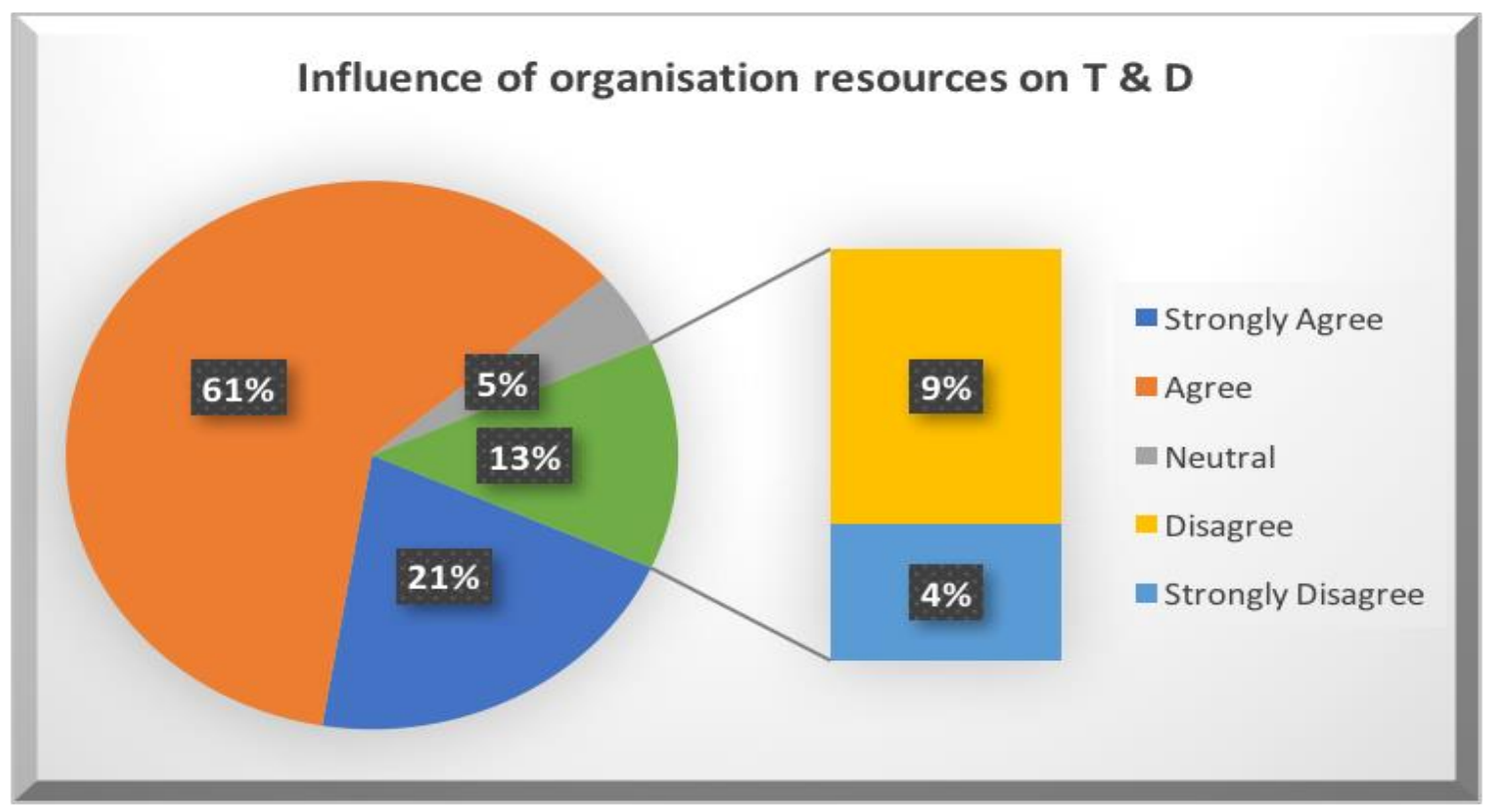

Figure 4.1. Influence of Organisation Resources on T \& D

Source: Field data, 2016

Also, one respondent among the key informant commented that;

"Our organisation (Chamwino District Council) offers much short-term training to our employees, where external trainers do train our personnel due to lack of internal trainers with required expertise to handle on-job trainings. Also, long-term training for individual career goals is supported by the council management" (Interview, name withheld, Chamwino DC, $18^{\text {th }}$ July 2017).

Therefore, the majority of respondents generally agreed on the influence of organisation resources on training and development in Tanzania's public sector, with evidence from two local authorities in Tanzania. This study extends the importance of organisation resources on successful implementation of training and development initiatives in organisations towards realizing organisation objectives.

\subsubsection{Modern Technology}

In respect to modern technology, the study sought to establish whether modern technology influence training and development in Tanzania's public sector. The results on figure 4.2 revealed that, out of 67 respondents, majority about $48.0 \%$ agreed and $24.0 \%$ strongly agreed while $9.0 \%$ were neutral. The rest few about $13.0 \%$ and $6.0 \%$ of respondents disagreed and strongly disagreed respectively. The findings in figure 4.2 correlate with Sambrook (2002) who supported that currently, rapidly changing technology and work reorganization has driven the need for training and development in modern organisations. Also, Rogers (1999) argues that change in technology as a key factor influencing training triggered by changes in 


\section{Macrothink}

Journal of Public Administration and Governance ISSN 2161-7104 2018, Vol. 8, No. 3

production process, tools and methods, changing firm needs, manufacturing settings, and even equipment due to technology advancement.

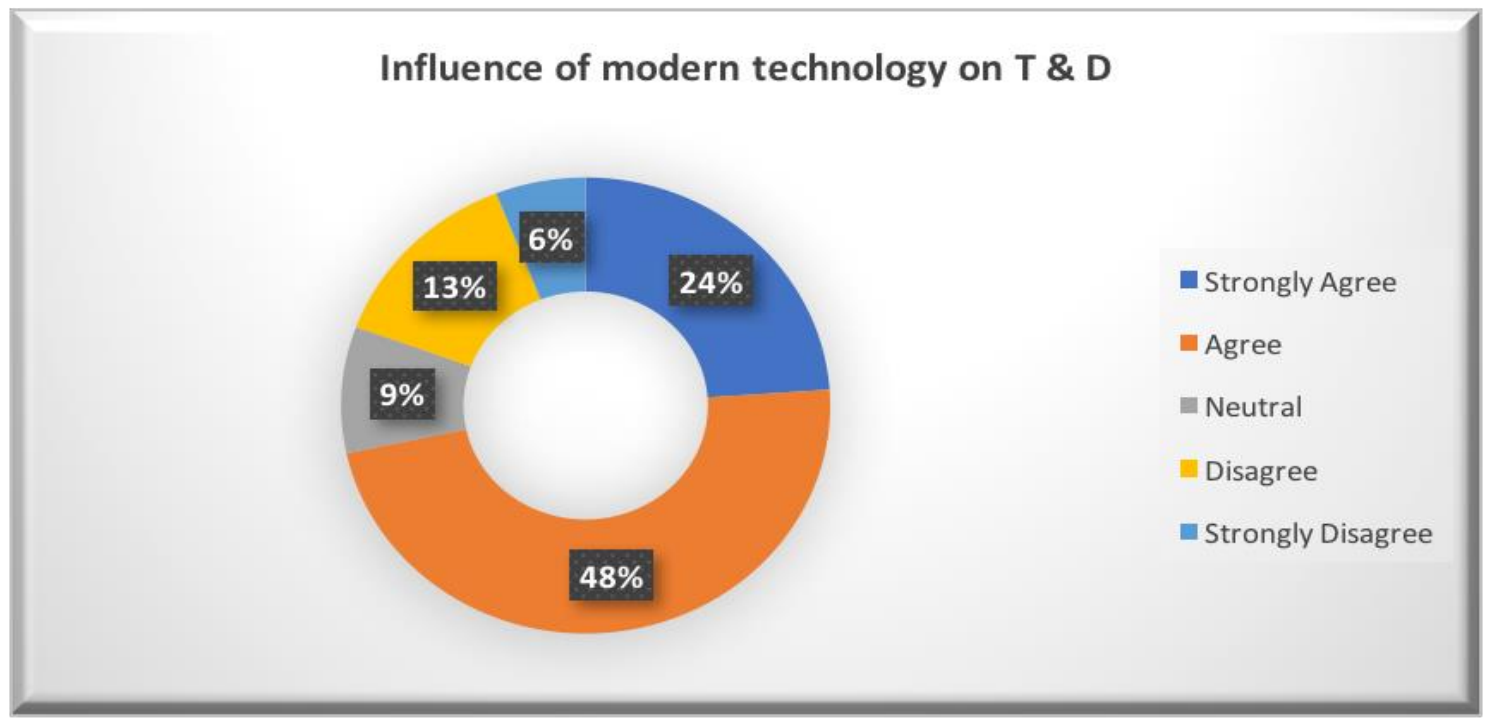

Figure 4.2. Influence of Modern Technology on T \& D

Source: Field data, 2017

The findings were further supported by Head of Human Resource who commented that:

"In our organization we normally train our employees to use new machines or facilities which are using advanced technology in order to improve efficiency and effectiveness in their operations. For instance, when modern computers were introduced in our council, all operators were involved in on-job training in order to master how to use those new facilities" (Interview, Dodoma municipal council, $20^{\text {th }}$ June 2017).

Therefore, the majority of respondents generally agreed on the influence of modern technology on training and development in Tanzania's public sector, especially in Tanzania local government authorities. This study extends the importance of technology on influencing training and development initiatives towards realizing organisation objectives.

\subsubsection{Organizational Structure}

In respect to organisation structure, the study sought to establish whether organisation structure affects training and development in Tanzania's public sector. The results on figure 4.3 revealed that, out of 67 respondents, majority about $40.0 \%$ agreed and $19.0 \%$ strongly agreed while $12.0 \%$ were neutral. The rest few about $17.0 \%$ and $12.0 \%$ of respondents disagreed and strongly disagreed respectively. The results agree with Ngiwra (2009) who argued that inflexible organisation structure does not facilitate training, but flexible does, it acts as a restraining factor and hence organisation structure may determine or encourage training and development. 


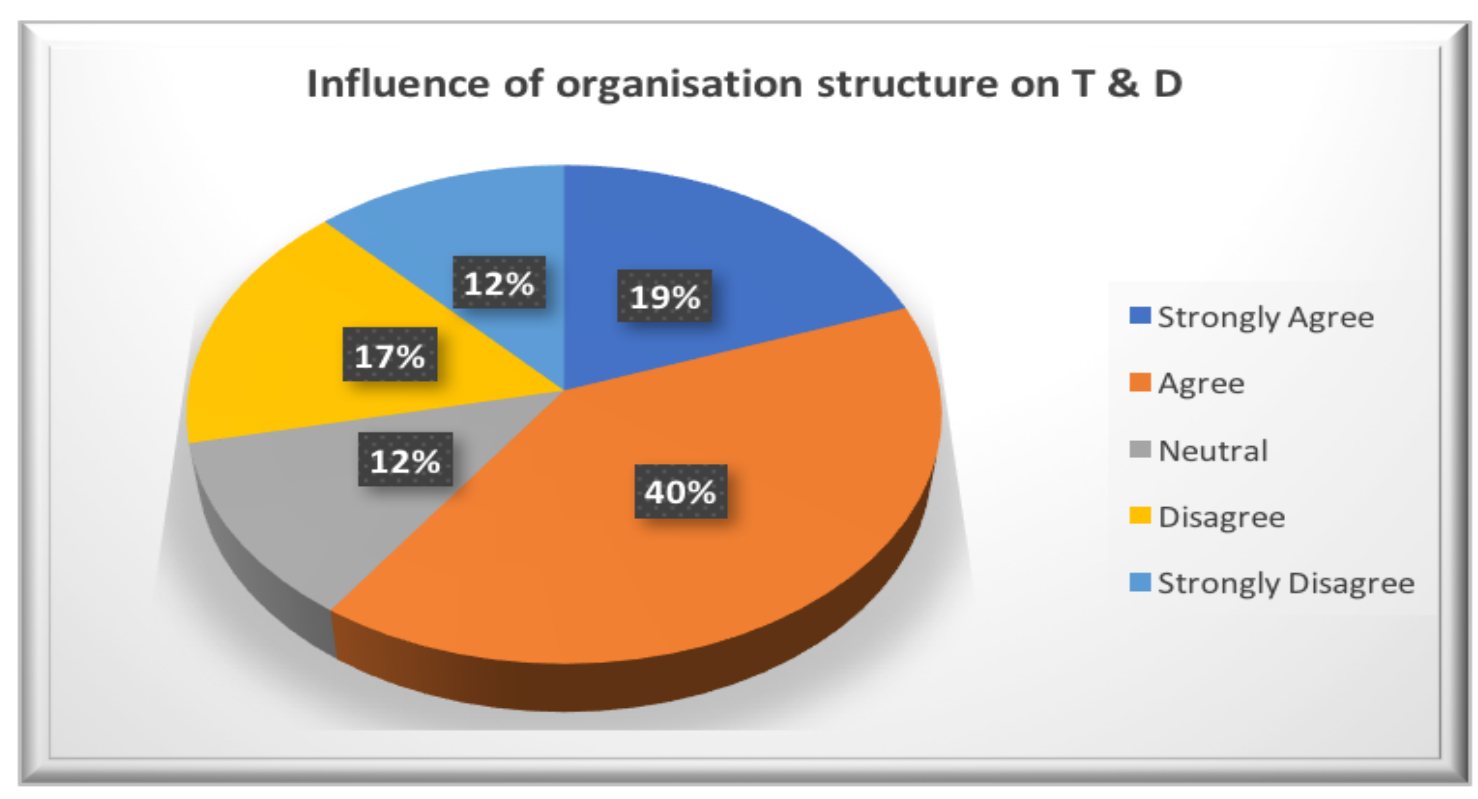

Figure 4.3. Influence of Organizational Structure on T \& D

Source: Field data, 2017

This was supported by Head of Human resources who lamented that:

"Employees who are possible candidate for promotions if are well trained in both short and long-term training in our council. This improves their competence and directly improves performance in their new roles. For instance, most of our heads of departments are possessing second degree at master's level" (Interview, Namewithheld, Chamwino DC, $20^{\text {th }}$ July 2017).

Therefore, the majority of respondents generally agreed on the influence of organisation structure on training and development in Tanzania's public sector. This study extends the importance of organisation structure towards executions of training and development initiatives in organisations in order to realize organisation objectives.

\subsubsection{Organisation Culture}

In respect to organisation culture, the study sought to establish whether culture influence training and development in Tanzania's public sector. The results on figure 4.4 revealed that, out of 67 respondents, majority about $33.0 \%$ agreed and $16.0 \%$ strongly agreed while $18.0 \%$ were neutral. The rest few about $21.0 \%$ and $12.0 \%$ of respondents disagreed and strongly disagreed respectively. The findings are in line with Arasa (2008) who argues that performance culture encourage training in organisation and help to reduces resistance to change among employees in the organisation. This was further supported by Heads of human resource in two local authorities who claimed that:

"In local authorities we encourage employees for long-term and attend short-term training in order to recuperate their skills towards improving their performance" (Interview, namewithheld, Dodoma MC and Chamwino DC, $18^{\text {th }}$ July 2017). 


\section{Macrothink}

Journal of Public Administration and Governance

ISSN 2161-7104

2018, Vol. 8, No. 3

Moreover, the results on organisation culture concur with Forman and Argenti (2005) argument that organisation culture influences the implementation of organisation strategies. It is seen as the catalyst or enabler for effective implementation of strategies (Alamsjah, 2011), and hence poor corporate culture may act as obstruction to successful implementation (Arasa, 2008).

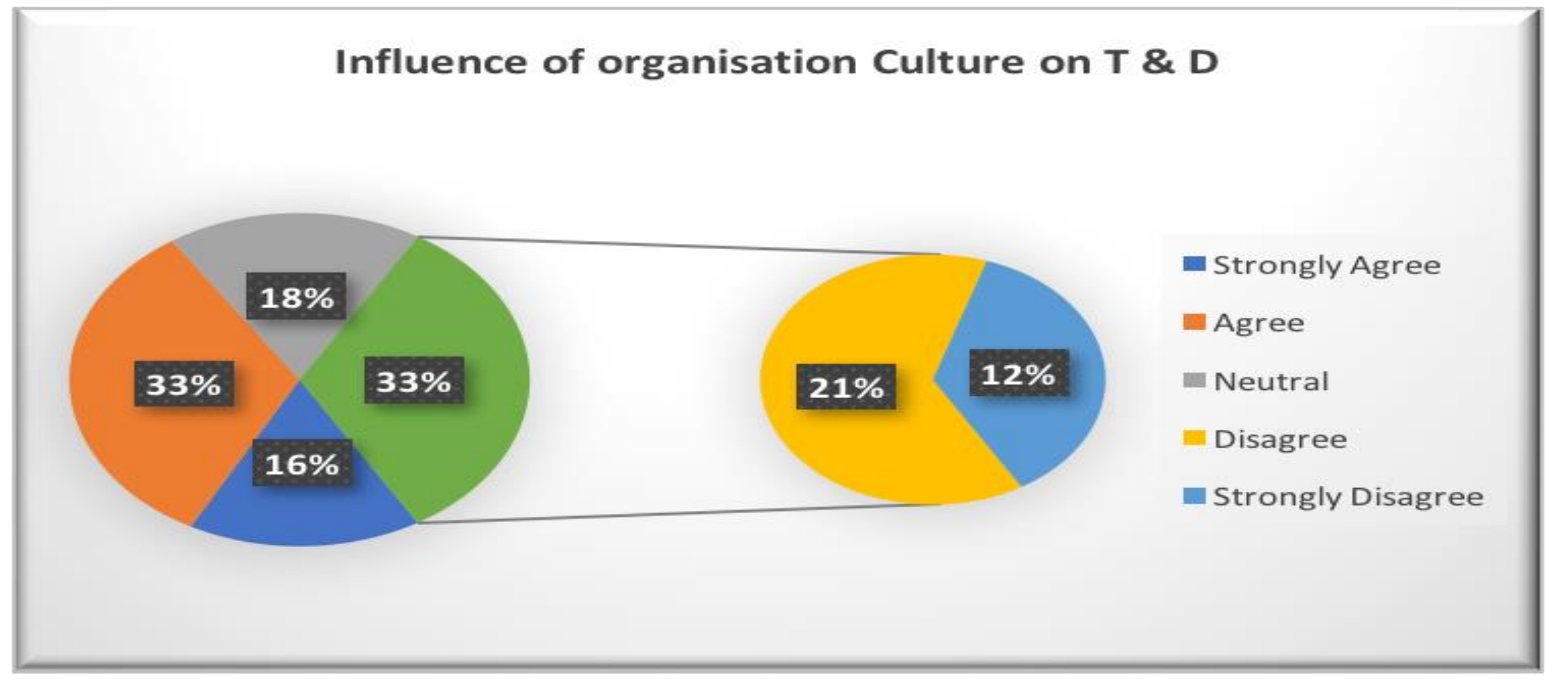

Figure 4.4. Influence of Organisation Culture on T \& D

Source: Field data, 2017

Therefore, the majority of respondents generally agreed on the influence of organisation culture on training and development in Tanzania's public sector. This study extends the importance of organisation culture towards executions of training and development initiatives in organisations in order to realize organization objectives.

\subsection{Inferential Statistics}

This part presents analysis using inferential statistics for all four variables in this study. Also, collective analysis is done.

\subsubsection{Correlation Analysis}

The findings from the Table 4.2 indicates that, Pearson correlation coefficient $(\mathrm{R})$ for organisation resource is 0.707 and statistically significant at $\mathrm{P}$-value $=0.000$; modern technology $\mathrm{R}=0.589$ and $\mathrm{p}$-value $=0.000$; Organisation structure $\mathrm{R}=0.363$ and $\mathrm{p}$-value $=$ 0.003 ; and organisation culture $\mathrm{R}=0.245$ and $\mathrm{p}$-value $=0.045$ respectively. 
Table 4.2. Correlations Matrix

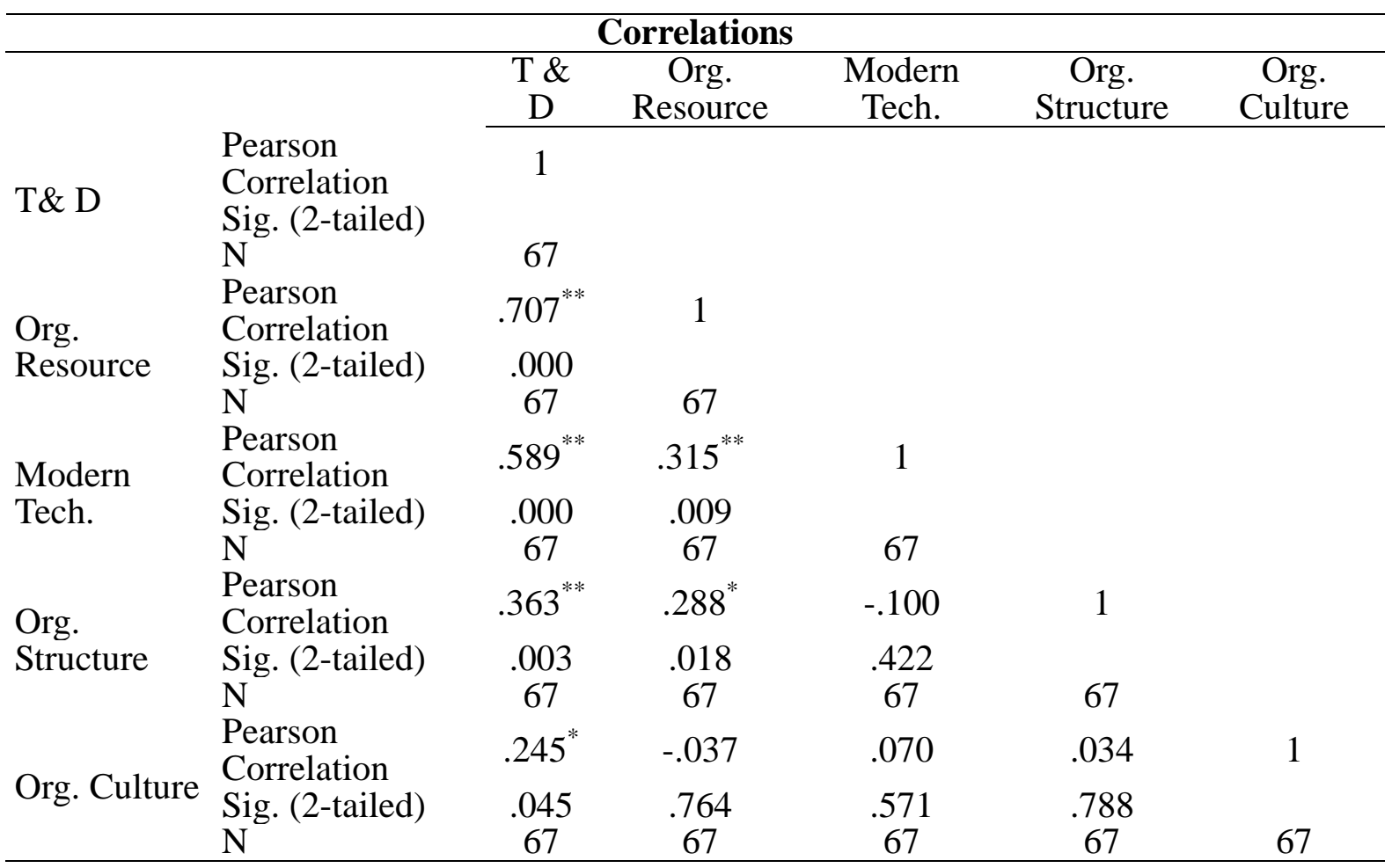

**. Correlation is significant at the 0.01 level (2-tailed).

*. Correlation is significant at the 0.05 level (2-tailed).

Therefore, the finding revealed that organisation resource has strong positive correlation with training and development and is statistically significant at $\mathrm{p}$-value $=0.000$. Also, modern technology has moderate positive correlation with training and development and statistically significant at $\mathrm{p}$-value $=0.000$. However, organisation structure and organisation culture had weak positive correlation with training and development but statistically significant at p-value $=0.003$ and 0.045 respectively.

\subsubsection{Multiple Regression Analysis}

The aim of the study was to determine the overall effect of independent variables (organisation resources, modern technology, organisation structure and organisation culture) on dependent variable (training and development in local government authorities). The findings in the table 4.3 indicate the Pearson correlation (R) of joint effect (all independent variables) on training and development is 0.873 at 0.05 level of significance. This implies that there is a strong positive correlation between all independent variables (joint effect) and training and development.

Table 4.3. Regression Model Summaryb

\begin{tabular}{ccccc}
\hline Model & $\mathrm{R}$ & R Square & Adjusted R Square & $\begin{array}{c}\text { Std. Error of the } \\
\text { Estimate }\end{array}$ \\
1 & $.873^{\mathrm{a}}$ & .762 & .747 & 4.061 \\
\hline
\end{tabular}


a. Predictors: (Constant), Organisation Culture, Organisation Structure, Modern Technology, Organisation Resource

b. Dependent Variable: Training and Development

The model $\mathrm{Y}=\beta_{0}+\beta_{1} X_{1}+\beta_{2} X_{2}+\beta_{3} X_{3}+\beta_{4} X_{4}+\varepsilon$ explained by $R^{2}=0.762$ indicated in table 4.3 , implies that $76.2 \%$ of the variations in training and development is influenced by independent variables (organisation resources, modern technology, organisation structure and organisation culture) in Tanzania's public sector. This means that other factors not studied in this research contributes about $23.8 \%$ on training and development in public sector.

Table 4.4. ANOVAa

\begin{tabular}{lrrrrc}
\hline Model & Sum of Squares & Df & Mean Square & F & Sig. \\
Regression & 3275.915 & 4 & 818.979 & 49.656 & $.000^{\mathrm{b}}$ \\
Residual & 1022.563 & 62 & 16.493 & & \\
Total & 4298.478 & 66 & & & \\
\hline
\end{tabular}

a. Dependent Variable: Training and Development

b. Predictors: (Constant), Organisation Culture, Organisation Structure, Modern Technology, Organisation Resource

Also, in order to test the goodness of fit of the linear model the null hypothesis of the study was $H_{0}$ : There is no goodness of fit of the dependent variable against the various independent variables; at significance level of 5\%. The results in table 4.4 shows the Analysis of Variance (ANOVA) which indicates that the model goodness of fit is significant at P-value $=0.000$ which is less than significance level of $0.05, \mathrm{~F}=49.656$ with 62 degrees of freedom. Hence, we reject the null hypothesis and conclude that there is goodness of fit of dependent variable against the various independent variables at alpha $=0.05$. Therefore, the model is statistically significant to predict how independent variables affects dependent variable in this study.

Table 4.5. Coefficient Matrix

\begin{tabular}{|c|c|c|c|c|c|}
\hline \multirow[t]{2}{*}{ Model } & \multicolumn{2}{|c|}{$\begin{array}{c}\text { Unstandardized } \\
\text { Coefficients }\end{array}$} & \multirow{2}{*}{$\begin{array}{l}\text { Standardized } \\
\text { Coefficients } \\
\text { Beta }\end{array}$} & \multirow[t]{2}{*}{$\mathrm{T}$} & \multirow[t]{2}{*}{ Sig. } \\
\hline & $\mathrm{B}$ & Std. Error & & & \\
\hline (Constant) & .490 & 4.281 & & .114 & .909 \\
\hline Organisation Resource & .448 & .062 & .504 & 7.244 & .000 \\
\hline Modern Technology & .253 & .039 & .439 & 6.550 & .000 \\
\hline Organisation Structure & .200 & .052 & .253 & 3.823 & .000 \\
\hline Organisation Culture & .124 & .034 & .225 & 3.604 & .001 \\
\hline
\end{tabular}

Further, the model as reflected in table 4.5 indicates that all independent variables were statistically significant at $\mathrm{p}$-value $=0.000 ; \mathrm{p}$-value $=0.000 ; \mathrm{p}$-value $=0.000$ and $\mathrm{p}$-value $=$ 0.001 respectively. The fitted model was:

$\mathrm{T} \& \mathrm{D}=0.490+0.448 \mathrm{X} 1-0.253 \mathrm{X} 2+0.200 \mathrm{X} 3+0.124 \mathrm{X} 4+\varepsilon$; where $\mathrm{T} \& \mathrm{D}=$ Training and 
Development, $\mathrm{X} 1=$ organisation resources, $\mathrm{X} 2=$ modern technology, $\mathrm{X} 3$ = organisation structure, $\mathrm{X} 4=$ Organisation culture, $\varepsilon=$ error term which means all variables (factors) which affect training and development but are not considered in this study. This implies that, organisation resource has a higher influence of training and development at $\beta=0.448$ and $\mathrm{p}$-value $=0.000 ;$ followed by modern technology with $\beta=0.253$ and $\mathrm{p}$-value $=0.000$; organisation structure with $\beta=0.200$ and $p$-value $=0.000$; and organisation culture with $\beta=$ 0.124 and $\mathrm{p}$-value $=0.001$ respectively. Therefore, even if the four variables contribute at a rate of zero still the model is positive at a rate of 0.490 , although practically this cannot easily happen or is practically impossible assumption in real practice.

\section{Conclusions}

The study shows that organization resources have strong positive correlation at $R=0.707$ and p-value of 0.000 . This reveled that there is statistically significant positive linear relationship between organisation resources and training and development; and $\beta=0.448$ indicates that organisation resources has higher contributions of $44.8 \%$ among the tested variables. Also, interview indicated that, financial resources support training and development in public sector for improving employees' knowledge, skills and abilities. Moreover, modern technology had $\beta=0.253$ which implies that, modern technology contributes about $25.3 \%$ on the need for training and development in Tanzania's public sector; where the majority of respondents agreed that due to the advancement of technology and use of modern tools, training has become the basic need to enhance employees' abilities towards attainment of organizational objectives. Further, organisation structure has $\beta=0.200$, which implies that, $20.0 \%$ of training and development is influenced by organisation structure in Tanzania's local authorities; and hence need for flexibility of organizational structures to allow innovation and creativity of head of departments in making changes which suit the need and demand in their organisation. Furthermore, organisation culture with $\beta=0.124$, implies that only $12.4 \%$ of training and development is affected by organisation culture in Tanzania's public sector.

\section{Recommendations}

Local authorities in Tanzania need to invest in on-going employees training and development for effective and efficient executions of day to day activities for quality service delivery. Sufficient budget is needed to fund training of local government staff for effective delivery of services in local authorities. Local authorities should regard training of staff as a continuous process due to rapid change of technology. Furthermore the government of Tanzania should create flexible structures for local governments to enable local authorities to be innovative and flexible so that they can to cope with changes which demand training. Training and development helps to retain and motivate employees and hence enhance their potential towards improving quality of work. Moreover, council management should make training and development of employees as a priority as well as value addition and not a cost for improving organization's productivity. Further, merit-based selection of employees for training to be guided by clear policy and training programme which will reduce complains from employees who are not selected for training programmes. 


\section{References}

Abok, A. M. (2013). Factors Affecting Effective Implementation of Strategic Plans in Non-Governmental Organisations In Kenya, JKUAT-Nairobi: unpublished report.

Alamsjah, F. (2011). Key Success Factors in Implementing Strategy: Middle-Level Managers' Perspectives; Procedia Social and Behavioural Sciences, 24(2011), 1444-1450. https://doi.org/10.1016/j.sbspro.2011.09.049

Arasa, R. M. (2008). The Challenges of Implementing Strategic Plans in Large Management Consultancies. University of Nairobi: Unpublished $\mathrm{PhD}$ thesis.

Armstrong, M. (2006). A Handbook of Human Resource Management. 10th ed., London Kogan page Ltd.

Awino, Z. B. (2007). The Effect of Selected Variables on Corporate Performance: A Survey of Supply Chain Management in Large Private Manufacturing Firms in Kenya. University of Nairobi: Unpublished report.

Barrington, K., \& Stimpson, P. (2002). Business studies, $2^{\text {nd }}$ Ed. Muray Publishers, London.

Chen, L. C. (2007). Aligning with Vision and Values. Journal of Leadership Excellence, $23(4), 6$.

Forman, J., \& Argenti, P. A. (2005). How Corporate Communication Influences Strategy Implementation, Reputation and the Corporate Brand: An Exploratory Qualitative Study. Corporate Reputation Review, 8, 245-264. https://doi.org/10.1057/palgrave.crr.1540253

Gordon, B. (2002). Are Canadian firms under investing in training? Canadian Business Economics, 1, 25-33.

Guest, D. (1987). Human Resource Management and Industrial Relations. Journal of Management Studies, 24, 503-521. https://doi.org/10.1111/j.1467-6486.1987.tb00460.x

Harrison, R. (2000) Employee Development. ( $2^{\text {nd }}$ ed) London, Institute of Personnel and Development.

Hill, C. W. L., \& Jones, G. R. (2013). Theory of Strategic Management. (10 ${ }^{\text {th }}$ ed). U.S.A: South -Western, Cengage Learning.

Jarzabkowski, P., \& Balogun, J. (2009). The Practice and Process of Delivering Integration Through Strategic Planning; Journal of Management Studies, 46(8), 1255-1288. https://doi.org/10.1111/j.1467-6486.2009.00853.x

Kothari, C. (2008) Research Methodology, Methods and Techniques. New Delhi: New Age International Publishers:

Lado, A. A., \& Wilson, C. M. (2004), human resource systems and sustained competitive advantage: a competency-based perspective, Cleveland state university.

McCourt, W., \& Derek, E. (2003). Global Human Resource Management: Managing People 


\section{Macrothink}

Journal of Public Administration and Governance

ISSN 2161-7104 2018, Vol. 8, No. 3

in Developing and Transitional Countries. Cheltenham, UK: Edward Elgar. https://doi.org/10.4337/9781781950104

Ngirwa, C. A. (2009). Human Resource management in African Work Organizations, National Printing Co. Ltd, Dar es Salaam

Noe, R. A. (2008). Employee training \& development (4th ed). New York: McGraw-Hill Irwin.

Okioga, C. K. (2012). Strategies Which Are Key to The Success of The Corporate Institution in Kenya. A Case of Selected Corporate Institutions in Kenya. European Journal of Business and Management, 4(15), 31-43.

Pearce, J. A., \& Robinson, R. B. (2009). Strategic Management: Formulation, Implementation and Control, 7 Ed. Homewood, IL: Richard D. IRWIN Inc.

Robson. C, (2002). Real World Research. A Resource for Social Scientists and Practitioner-Researchers (Second Edition).

Rogers, M. (1999). Innovation in Australian workplaces: An empirical analysis, Australian Bulletin of Labour, 25(4).

Russo. M. V., \& Fouts, P. A. (2007). A resource-based perspective on corporate environmental performance and profitability. University of Oregon, Golden Gate University

Sambrook, S. (2002). Factors Influencing learning in work. European Educational Research journal, 3. https://doi.org/10.2304/eerj.2002.1.3.8

Sekaran, U., \& Bougie, R. (2009). Research Methods for Business: A Skill Building Approach, $5^{\text {th }}$ Ed. John Wiley \& Sons Ltd., United Kingdom.

Torrington, D., \& Hall, L. (2008). Human Resource Management. London Prentice hall International (UK Ltd)

Wheelen, T. L., \& Hunger, J. D. (2000). Strategic Management and Business Policy. Entering 21 st Century Global Society. Addison Wesley Longman, Inc.

\section{Copyright Disclaimer}

Copyright for this article is retained by the author(s), with first publication rights granted to the journal.

This is an open-access article distributed under the terms and conditions of the Creative Commons Attribution license (http://creativecommons.org/licenses/by/4.0/). 